\title{
$\underline{\mathrm{O} J \mathrm{ED}}$
}

Volume 5, Issue S1 (2020), pp. 1-7 Journal of School Administration Research and Development ISSN: 2470-8496 Print/ ISSN: 2470-850X Online ojed.org/index.php/JSARD

\section{Reexamining "Perfect" Attendance in Schools}

\author{
David L. Conrad \\ Governors State University, University Park, IL, United States
}

\begin{abstract}
The COVID-19 emergency has created new challenges for schools regarding student attendance. The predominant practice of "perfect" attendance incentives in schools conflicts with new government policies regarding student self-quarantine due to the COVID-19 virus. School leaders must change their procedures and communication regarding student attendance to reflect these new conditions.
\end{abstract}

Keywords: COVID-19, schools, student attendance, truancy

In 2013, nationwide news media broadcast a human-interest story about a Michigan postal worker who-after 44 years of employment-was retiring without ever taking a sick day. The worker explained she could "shake it off" (Kim, 2013, para. 5) and go to work even when she felt ill. In 2015, an Alabama police officer had worked for 35 years without using sick leave, "without ever giving in to a queasy stomach, a sniffle or an achy body" (Reeves, 2015, para. 3). While these accomplishments were portrayed as examples of strong work ethic, COVID-19 has taught us that staying home is often required - not just for our own recovery, but for the safety of others. Perfect attendance may seem laudable, but how many sick workers have infected their peers because they decided to "shake it off" instead of staying home? 
Schools have traditionally promoted the concept of "perfect" attendance for their students, and attendance incentives are ingrained in school culture. Schools incentivize students by rewarding "perfect" attendance with pizza parties, certificates, field trips, and prize drawings (Ely \& Fermanich, 2013; Robinson et al., in press). However, many state COVID-19 policies call upon school leaders to enforce local procedures to keep students away from school who have symptoms of COVID-19, were exposed to known carriers of the virus, or have health vulnerabilities that increase their susceptibility to the virus. How will school leaders reconcile these conflicting messages of "perfect" attendance and quarantine policies that prevent students from attending school?

\section{“PERFECT" ATTENDANCE IS IMPERFECT}

Promoting "perfect" attendance seems logical. Research has established the relationship between student attendance and achievement: higher attendance rates are positively correlated with higher student achievement (Black et al., 2014; Gottfried, 2010). In addition, many state and federal policies incentivize schools to maximize student attendance, including states where school funding is influenced by student attendance. Schools are motivated to increase student attendance to yield higher state funding allocations, and states that connect funding to attendance yield higher graduation and lower truancy rates than other states that do not entangle funding with student attendance (Ely \& Fermanich, 2013).

Attendance is vitally important for student achievement, but "perfect" attendance standards have four inherent flaws. First, "perfect" attendance places others at risk of illness when unhealthy students attend school to maintain their "perfect" status and unduly risk transmission to others. This unintended consequence will undermine governments' efforts to suppress the COVID-19 virus. Second, while chronic absenteeism is a significant problem, perfection is not an elixir for truancy. Chronic absenteeism is a wicked problem whose causes intersect student, family, school, and community challenges. Research suggests successful attendance improvement interventions go beyond incentives to address these myriad causes (Black et al., 2014; Maynard et al., 2012; Robinson et al., 2018). Third, while research suggests incentives and rewards may increase student attendance rates (Taylor-Price, 2012; Young et al., 2020), research also suggests incentives may have the unintended consequence of reducing 
student motivation to attend school. In absence of an incentive, student attendance may decline (Banerjee et al., 2012; Robinson et al., in press). In addition, once a child is absent for one school day, "perfect" attendance incentives stop working because the student cannot recover from the "all or nothing" criteria. Fourth, focusing on student incentives may distract school leaders from addressing other mediating factors that schools have direct control over. Research suggests teachers significantly influence student attendance (Gershenson, 2016). Engaging instruction-specifically the school culture for engaging teaching practices that increase student interest and reduce student boredom-motivates more students to attend school (Black et al., 2014; Liu \& Loeb, 2016; Maynard et al., 2012).

Ironically, the students for whom perfection is expected are taught by adults whose own attendance has been investigated. The scholarship on adults in schools and other workplaces provides some insights. The National Center for Teacher Quality suggested that most common teacher attendance policies were ineffective because teacher attendance is more positively influenced by "school-based norms that shape the culture and tone around teacher attendance" (Joseph et al., 2014, p. 14). Teacher attendance incentives may work initially, but implementation fatigue may eliminate any short-term gains as absences eventually rise to the levels prior to the new incentives (Taylor-Price, 2012). Other literature supports creative and accommodating workplace standards. One school district created an adult incentive that included both "perfect" and "near perfect" attendance. Through various financial rewards and recognition opportunities, staff attendance increased by $16 \%$ (Freeman \& Grant, 1987). International research suggested a direct relationship between teacher attendance and student attendance when both parties become mutually accountable for the shared benefits of attendance (Banerjee et al., 2012). Workplace studies outside of education found that financial incentives for punctuality or recognition for "good" attendance that allowed some time-off might improve worker attendance (Camden et al., 2011; Markham et al., 2002). However, policies that promoted "perfect" attendance hindered workers' motivation. Workers "gamed" the procedures to earn the incentive and attendance rates declined once workers were ineligible for the incentive (Gubler et al., 2016).

How will school leaders manage student attendance during COVID19? Many schools attending face-to-face will proffer remote learning options as viable learning equivalents for absent students, but recent 
experience suggests many schools and their communities are ill-equipped for quality remote learning (Walters, 2020). Besides, how will the challenges of concurrent remote learning be managed by teachers coping with the added stress of COVID-19 conditions in their own families? These challenges will confound schools' ability to meet the needs of all learners.

\section{CONCLUSION}

The standard of "perfect" attendance is inherently flawed and inappropriate for children. Rather than perfection, the new vision of school attendance must reflect our understanding of pandemic hygiene - a reasonable and medically-advised standard of staying home when your health unduly poses a risk to others. Given the COVID-19 policies calling for vulnerable, symptomatic, and exposed students to stay home, local procedures must encourage these students to stay home, and when medically feasible, continue their attendance remotely for synchronous learning with their teachers and peers. To ensure successful implementation, schools must allocate the human and technology capital needed to provide equitable access for all students to learn remotely. This includes robust home internet access, 1:1 student computers, webcasting equipment in every classroom, and training and technical support for teachers who must embrace new learning modalities. When implemented, these practices have the potential to maximize student learning while creating safer learning spaces for all.

\section{REFERENCES}

Banerjee, R., King, E. M., Orazem, P. F., \& Paterno, E. M. (2012). Student and teacher attendance: The role of shared goods in reducing absenteeism. Economics of Education Review, 31(5), 563-574. https://doi.org/10.1016/j.econedurev.2012.04.002

Black, A. T., Seder, R. C., \& Kekahio, W. (2014). Review of research on student nonenrollment and chronic absenteeism: A report for the Pacific Region (REL 2015-054). U.S. Department of Education, Institute of Education Sciences, National Center for Education Evaluation and Regional Assistance, Regional Educational Laboratory Pacific. https://ies.ed.gov/ncee/edlabs/regions/pacific/pdf/REL_2014054.pdf 
Camden, M. C., Price, V. A., \& Ludwig, T. D. (2011). Reducing absenteeism and rescheduling among grocery store employees with point-contingent rewards. Journal of Organizational Behavior Management, 31(2), 140-149. https://doi.org/10.1080/01608061.2011.569194

Ely, T. L., \& Fermanich, M. L. (2013). Learning to count: School finance formula methods and attendance-related student outcomes. Journal of Education Finance, 38(4), 343-369. https://www.jstor.org/stable/23597241

Freeman, R. R., \& Grant, F. D. (1987). How we increased staff attendance by 16 percent and saved \$156,000. American School Board Journal, $174(2), 31$.

Gershenson, S. (2016). Linking teacher quality, student attendance, and student achievement. Education Finance and Policy, 11(2), 125149. https://doi.org/10.1162/edfp_a_00180

Gottfried, M. A. (2010). Evaluating the relationship between student attendance and achievement in urban elementary and middle schools. American Educational Research Journal, 47(2), 434-465. https://doi.org/10.3102/0002831209350494

Gubler, T., Larkin, I., \& Pierce, L. (2016). Motivational spillovers from awards: Crowding out in a multitasking environment. Organization Science, 27(2), 286-303. https://doi.org/10.1287/orsc.2016.1047

Joseph, N., Waymack, N., \& Zaleski, D. (2014). Roll call: The importance of teacher attendance. National Council on Teacher Quality. https://files.eric.ed.gov/fulltext/ED556249.pdf

Kim, S. (2013, January 29). Postal worker retires after 44 years without sick day.

$\mathrm{ABC}$

News.

https://abcnews.go.com/blogs/business/2013/01/postal-workerretires-after-44-years-without-sick-day

Liu, J., \& Loeb, S. (2016). Going to school is optional: Schools need to engage students to increase their lifetime opportunities (Evidence speaks) [Report]. Brookings Institute. https://www.brookings.edu/research/going-to-school-is-optionalschools-need-to-engage-students-to-increase-their-lifetimeopportunities/ 
Markham, S. E., Scott, K. D., \& McKee, G. H. (2002). Recognizing good attendance: A longitudinal, quasi-experimental field study. Personnel Psychology, 55(3), 639-660. https://doi.org/10.1111/j.1744-6570.2002.tb00124.x

Maynard, B. R., McCrea, K., Pigott, T. D., \& Kelly, M. S. (2012). Indicated truancy interventions: Effects on school attendance among chronic truant students. Campbell Systematic Reviews, 8(1), 1-84. https://doi.org/10.4073/csr.2012.10

Reeves, J. (2015, October 2). After 35 years and no sick days, police officer Mike Flowers is finally retiring. Tuscaloosa News. https://www.tuscaloosanews.com/news/20151002/after-35-yearsand-no-sick-days-police-officer-mike-flowers-is-finally-retiring

Robinson, C. D., Gallus, J., Lee, M. G., \& Rogers, T. (in press). The demotivating effect (and unintended message) of awards. Organizational Behavior and Human Decision Processes. https://doi.org/10.1016/j.obhdp.2019.03.006

Robinson, C. D., Lee, M. G., Dearing, E., \& Rogers, T. (2018). Reducing student absenteeism in the early grades by targeting parental beliefs. American Educational Research Journal, 55(6). https://doi.org/10.3102/0002831218772274

Taylor-Price, A. R. (2012). Effect of the teacher incentive pay program in the Center School District [Doctoral dissertation, Baker University]. http://www.bakeru.edu/images/pdf/SOE/EdD_Theses/Price_Angela. pdf

Walters, A. (2020). Inequities in access to education: Lessons from the COVID 19 pandemic. Brown University Child and Adolescent Behavior Letter, 36(8), 8. https://doi.org/10.1002/cbl.30483

Young, S., Sollose, L. C., \& Carey, J. P. (2020). Addressing chronic absenteeism in middle school: A cost-effective approach. Children \& Schools, 42(2), 131-138. https://doi.org/10.1093/cs/cdaa009

DAVID L. CONRAD, Ed.D., is an Assistant Professor of Education and coordinator of the Educational Administration program at Governors State University, University Park, IL, United States. His research interests include teacher evaluation, education policy, and leadership preparation. Email: dconrad@govst.edu 
Manuscript submitted: July 9, 2020

Manuscript revised: September 21, 2020 Accepted for publication: September 23, 2020 